\title{
Electrical energy production from plant biomass: an analysis model development for pandanus amaryllifolius plant microbial fuel cell
}

\author{
Teng Howe Cheng ${ }^{1}$, Kok Boon Ching ${ }^{2}$, Chessda Uttraphan ${ }^{3}$, Yee Mei Heong ${ }^{4}$ \\ ${ }^{1,2}$ Department of Electrical Power Engineering, Universiti Tun Hussein Onn Malaysia, Malaysia \\ ${ }^{3}$ Department of Computer Engineering, Universiti Tun Hussein Onn Malaysia, Malaysia \\ ${ }^{4}$ Department of Engineering Education, Universiti Tun Hussein Onn Malaysia, Malaysia
}

\begin{abstract}
Article Info
ABSTRACT

Article history:

Received Oct 6, 2019

Revised Dec 8, 2019

Accepted Dec 22, 2019

\section{Keywords:}

Biomass

Electrochemical energy

Pandanus amaryllifolius

Plant microbial fuel cell model

bioelectricity

Plant microbial fuel cell (P-MFC) is an electrochemical reactor that converts organic compounds to electrical energy through the catalytic reaction from electrochemically active bacteria (EAB). However, there is no sign of an attempt in developing the functional model in predicting the energy conversion and utilization of P-MFC. In this study, an analytic model is proposed to show the whole production process of the organic compound to electrical energy generation. Pandanus Amaryllifolius plant was used as sources of photosynthate, where biomass product from rhizodeposition, acetate was produced, and soil bacteria as the microbial culture, and air as the input to the cathode chamber. The proposed analytical model is able to predict the output of the P-MFC using the parameters from the experiment. The generated data from the model was then compared with the monitored data from the Pandanus Amaryllifolius P-MFC. The results show the electrical power output has a high similarity pattern with the bacterial growth curve model and able to achieve the coulombic efficiency of $95.32 \%$.
\end{abstract}

Copyright () 2020 Institute of Advanced Engineering and Science. All rights reserved.

\section{Corresponding Author:}

Teng Howe Cheng,

Department of Electrical Power Engineering,

Faculty of Electrical and Electronic Engineering,

Universiti Tun Hussein Onn Malaysia,

Parit Raja, 86400 Batu Pahat, Johor, Malaysia.

Email: ge170107@siswa.uthm.edu.my

\section{INTRODUCTION}

From the last decade, scientists had been progressing to tackle global warming and pollution caused by conventional energy generation with an attempt to replace them with renewable energy that induces less harm to the environment. One of the new evolving technology is plant microbial fuel cell (P-MFC) [1-3], converting organic waste into electrical energy without harming the environment. In previous research, there are only a few numbers of models developed [4-6]. However, those models describe only the electrical reaction of conventional MFC but not based on plant biomass production [7] which covers the overall fundamentals.

Supposedly, Pandanus Amaryllifolius P-MFC can generate electrical energy by utilizing the microorganism's metabolisms in the rhizosphere. Thru photosynthesis, the plant produces nutrients in an amount that needed for plant growth and extra nutrients that are unutilized will be released into the rhizosphere [8-12]. This is where microbe functions as an oxidizing agent, reducing the organic substrate that is released. During the oxidation process, electrochemically active bacteria (EAB) releases protons and electrons, where these electrons were collected and utilized to generate energy. Nevertheless, there was no study on how the nutrient released relates to the production of electrical energy. 
In this paper, a model was developed to show various factors that affect the energy generation from P-MFC such as light intensity, temperature, $\mathrm{pH}$ and humidity [13]. The analytical mathematical model explains the effects of those parameters and predicts the energy generation based which is then compared to experimental data.

\section{METHODOLOGY}

\subsection{Experimentations}

The assessment first requires the setting up of P-MFC, using Pandanus Amaryllifolius as the main source of substrate for the microbes. The fuel cell chamber is constructed using plastic bottles with a capacity of five liters. The pyramid-shaped internal vessel can hold up to a total volume of $1600 \mathrm{~cm}^{3}$ of soil, where the bottle cap at the bottom tip is perforated to enable the flow of excessive water. Graphite electrode with a length of $10 \mathrm{~cm}$ and a diameter of $1 \mathrm{~cm}$ are prepared as the anodes and cathodes of the P-MFC. Each electrode is then tied by a $0.6 \mathrm{~mm}$ single-core copper wire to lengthen the possible measurement distance. The graphite electrodes for the cathodes are then wrapped inside a cellulose membrane to distinguish it from the anode. The anode electrode with the same dimension as the cathode electrode is then placed under the roots of the Pandanus Amaryllifolius plant before it is covered with the soil. An external resistor of $1 \mathrm{k} \Omega$ was connected to complete the circuit before connecting it to Arduino. The experimental setup is shown in Figure 1.

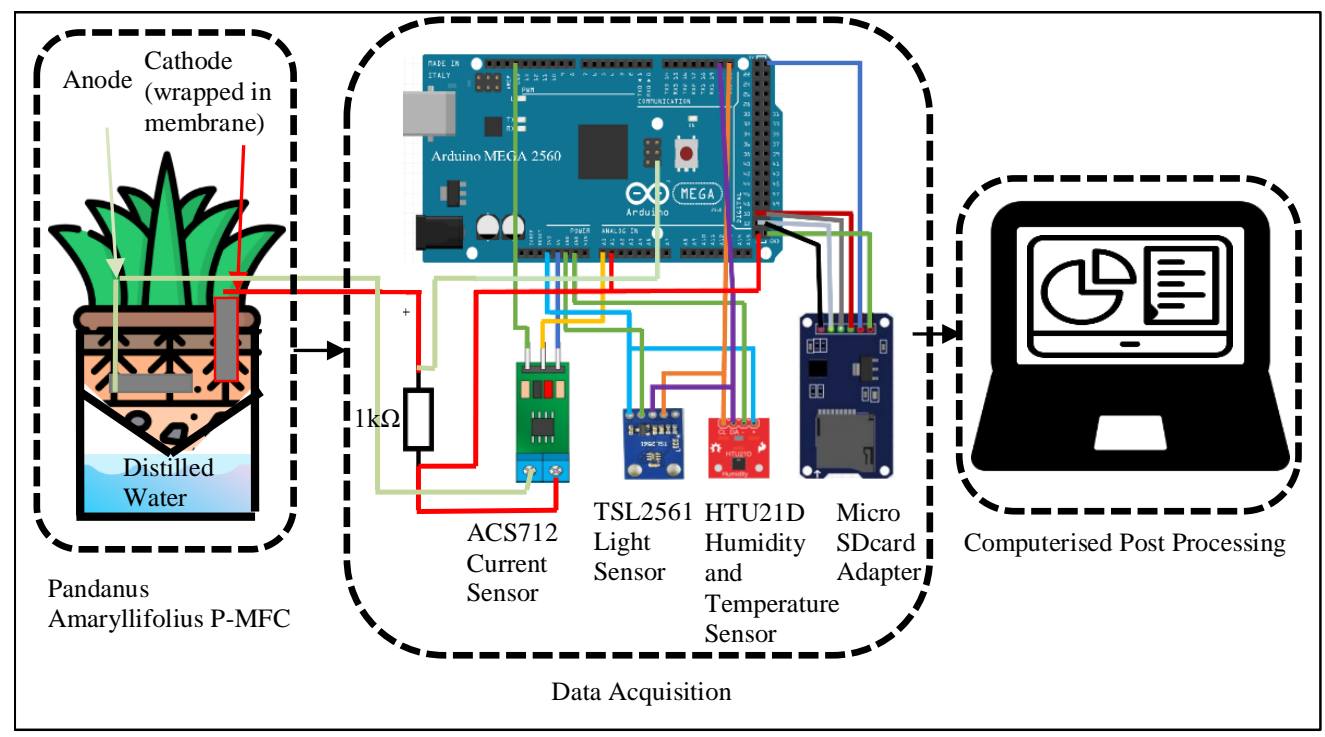

Figure 1. Scheme of Pandanus Amaryllifolius P-MFC experiment setup

P-MFC are then placed outdoor for five days to ensure normal daily sunlight exposure as to promote plant photosynthesis and bacteria growth. The soil of the vessel is watered regularly to retain the dampness, as humidity is one of the important aspects that keep the electron flow efficiently. Other parameters such as voltage, current, temperature, light intensity, and $\mathrm{pH}$ are taken periodically using the Arduino data acquisition system and AMTAST AMT-300 soil meter once every three hours.

The soil is tested for carbon compound at the start and the end of the experiment, where the $16 \mathrm{~g}$ of soil harvested is flushed with $\mathrm{N}_{2}$ three times to establish an anaerobic condition and added with $250 \mathrm{ml}$ of sterile anaerobic mineral solution containing $\mathrm{NaHCO}_{3}, \mathrm{KH}_{2} \mathrm{PO}_{4}, \mathrm{MgCl}_{2} .6 \mathrm{H}_{2} \mathrm{O}, \mathrm{NaCl}, \mathrm{NH}_{4} \mathrm{Cl}, \mathrm{CaCl}_{2} .2 \mathrm{H}_{2} \mathrm{O}$, cysteine, and $\mathrm{HCl} . \mathrm{H}_{2} \mathrm{O}$. The soil sample is then shaken thoroughly by a shaker for two hours. The presence of aliphatic acids and monomeric aromatic compounds in the soil suspensions are determined by highperformance liquid chromatography (HLPC). Once the data were gathered, they were plotted with OriginPro 2016 and post-processed by MathCad Prime 5.0 software.

\subsection{Plant Rhizodeposition Rate Model Development}

In the previous year, various research had led to adequate data, permitting a quantitative combination of the possible effect of leaf nitrogen $(\mathrm{N})$ content on carbon dioxide $\left(\mathrm{CO}_{2}\right)$ assimilation rates and 
carbon (C) biomass deposition in soil $[14,15]$. Due to the higher similarity of maize plant and Pandanus Amaryllifolius plant, the experiment suggests that the assimilation of $\mathrm{CO}_{2}$ by Pandanus Amaryllifolius plant is approximated by using the following equation:

$$
C_{A, \text { pandan }}^{*}=2.5 \times\left[\frac{2}{1+e^{\left(-4.0 \times\left(N_{A}-0.2\right)\right)}}-1\right]
$$

The maximum $C_{A \text {, pandan }}^{*}$ is $2.5 \mathrm{mg} \mathrm{CO}_{2} \mathrm{~m}^{-2} \mathrm{~s}^{-1}$ and becomes zero when the $N_{A}$ receded to $0.2 \mathrm{~g} \mathrm{~N} \mathrm{~m}^{-2}$. However, there are considerations that are needed in order to determine the overall carbon assimilation. The simple two-leaf model was used as leaf area index (LAI) reference [16-20]. The fraction of direct radiation intercepted is then calculated using the exponential equation:

$$
F=1-e^{\left(-L A I \times \frac{G}{\sin (\alpha)}\right)}
$$

Shadow projection $G$ were fixed at 0.5 . $L A I$ that intercepts direct radiation $\left(L A I_{\text {sun }}\right)$ obtained by using:

$$
L A I_{\text {sun }}=F \times \frac{\sin (\alpha)}{G}
$$

Next, $L A I$ that were exposed to dispersed radiation $\left(L A I_{\text {shade }}\right)$ is:

$$
L A I_{\text {shade }}=L A I-L A I_{\text {sun }}
$$

Radiation flux density which is dependent on radiation flux density occurrence to the canopy ( $I_{o}$ ), $F$, and $L A I_{\text {sun }}$ were estimated:

$$
I_{\text {sun }}=I_{o} \times \frac{F}{L A I_{\text {sun }}}
$$

Similar to (5), $I_{\text {shade }}$ is estimated, assuming $20 \%$ of the intercepted radiation is dispersed:

$$
I_{\text {shade }}=0.2 \times I_{o} \times \frac{F}{L A I_{\text {shade }}}
$$

Carbon assimilation is then calculated using (1) - (6):

$$
C_{A}=C_{A}^{*}\left[1-e^{\left(-E \times \frac{I_{o}}{C_{A}^{*}}\right)}\right]
$$

The value $E$ was set equal to $5.0 \mathrm{gCO}_{2} \mathrm{MJ}^{-1}$, which then can be derived based on sun and shade situation:

$$
\begin{aligned}
& C_{\text {sun }}=L A I_{\text {sun }} C_{A, \text { pandan }}^{*}\left[1-e^{\left(-E \times \frac{I_{\text {sum }}}{C_{A}^{*}}\right)}\right] \\
& C_{\text {shade }}=L A I_{\text {shade }} C_{A, \text { pandan }}^{*}\left[1-e^{\left(-E \times \frac{\left.I_{\text {shade }}\right)}{C_{A}^{*}}\right]}\right]
\end{aligned}
$$
(8) and (9).

Total carbon assimilation by the Pandanus Amaryllifolius plant can be determined by summing 
The carbon assimilation rate in the plant will be converted into biomass release [21-23]. Assuming acetate is the exudate, multiplying the assimilation rate with the acetate molecular weight per carbon $(24.022 / 59.044 \approx 2 / 5)$ accumulates the weight of biomass released by the plant. However, $40 \%$ of the biomass is considered to be utilized by the plant itself as respiration needs. Biomass released by Pandanus Amaryllifolius can be calculated by:

$$
B_{\text {pandan }}=0.6 \times \frac{2}{5} \times\left(C_{\text {sun }}+C_{\text {shade }}\right)
$$

\subsection{Modeling of Microorganism Growth and Reaction in the Rhizosphere}

Microbes are the most essential element in P-MFC, which consumes the biomass from plant exudation, called organic substrate. Electrochemically active bacteria (EAB) such as Geobacter sulfurreducens sp. and Shewanella Oneidensis MR-1 [24, 25] are the few species of microbes that were able to produce electrons while oxidizing organic substrate. Nevertheless, the actual number of these bacteria activity is difficult to be determined. Hence, fundamental models for bacteria were analyzed to estimate the behavior in the rhizosphere.

\subsubsection{Bacteria Logistic Growth Model}

There are several factors that are needed to be considered in bacteria growth $[5,26,27]$. The rate of growth is dependent on the availability of substrate, which will degrade and die when there is no more substrate left. In P-MFC, the bacteria growth is not limited to the substrate, since there is a continuous supply of substrate through photosynthesis, but limited to vessel space. Hence, the logistic growth model was used instead of using the Monod growth model.

Usually, bacteria cultures grow by binary fission in the presence of unlimited food, though controlled by the specific growth rate in an amount of time:

$$
X=X_{o} e^{\mu t}
$$

Where $X$ is the cell number or concentration, $X_{o}$ is the initial cell number or concentration at $t=1$, and $\mu$ or $\mu_{m}$ is the specific growth rate which is characteristic of a particular bacterial species.

Substrate concentration and cell growth relationship can be expressed as:

$$
\frac{d X}{d t}=-Y \frac{d S}{d t}
$$

As the cell grows, they use substrate $(S)$ so it disappears. $Y$ is a yield factor that is less than 1 as not all substrate goes into cells for synthesis.

Since P-MFC supply substrate for cell growth, hence by assuming unlimited substrate, logistic growth is stated as:

$$
\frac{d X}{d t}=\mu_{m} X\left(1-\frac{X}{X_{f}}\right)
$$

Where $X_{f}$ is the maximum population size for bacteria which is restricted by vessel available space. Table 1 shows the parameters estimated for the experiment.

Table 1. Parameters Used for Growth Curve

\begin{tabular}{cc}
\hline Parameter & Value (Unit) \\
\hline$X$ & $50 \mathrm{mg} \mathrm{m}^{-3}, t=0$ \\
$X_{f}$ & $5000 \mathrm{mg} \mathrm{m}^{-3}$ \\
$\mu_{m}$ & $0.4 d^{-1}$ \\
$t$ & $30 d \quad$ (day) \\
\hline
\end{tabular}




\subsubsection{Electron Extraction from an Oxidizing Substrate}

In order to grow, microbes in the rhizosphere need substrate as food. Acetate is the preferred electron donor [28] for EAB like Geobacter; oxidizing it to produce energy for growth and electrons for electrode reduction while providing carbon. The overall chemical reaction is shown as:

$$
2 \mathrm{CH}_{3} \mathrm{COO}^{-}+\mathrm{H}^{+}+2 \mathrm{H}_{2} \mathrm{O} \rightarrow 2 \mathrm{CO}_{2}+4 \mathrm{H}_{2}
$$

This endergonic reaction can only be achieved when hydrogen partial pressure is kept low with syntrophic cooperation with Wolinella succinogenes or Desulfovibrio desulfuricans and nitrate as an electron acceptor under standard thermodynamic conditions [29].

In P-MFC anodic conditions, acetate and water are converted into bicarbonate, hydrogen atoms and electrons:

$$
\mathrm{CH}_{3} \mathrm{COO}^{-}+4 \mathrm{H}_{2} \mathrm{O} \underset{E A B}{\longrightarrow} 2 \mathrm{HCO}_{3}^{-}+9 \mathrm{H}^{+}+8 e^{-}
$$

Electrons released were then passed through the external circuit and collected by the cathode, while hydrogen atom penetrates the membranes [30] to the cathode [31] to form water with oxygen from the surroundings:

$$
2 \mathrm{O}_{2}+8 \mathrm{H}^{+}+8 e^{-} \rightarrow 4 \mathrm{H}_{2} \mathrm{O}
$$

The anodic and cathodic reaction for P-MFC cell is illustrated in Figure 2.

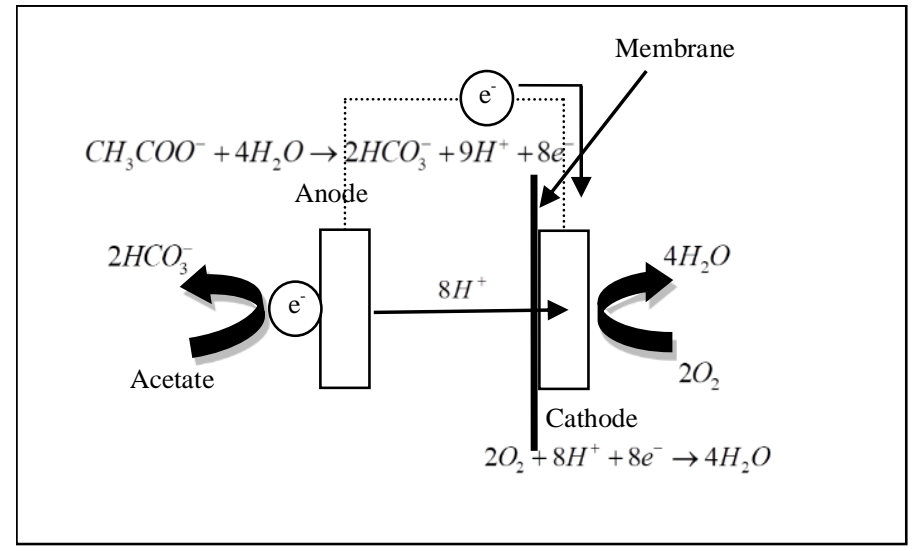

Figure 2. The reaction between anode and cathode in P-MFC cell

\section{RESULTS AND DISCUSSION}

\subsection{The Conversion Efficiency of Plant Biomass to Acetate}

After 120 hours of experimentation, the Pandanus Amaryllifolius plant rhizodeposition rate is validated with the detection of acetate in soil, which is the carbon compound released by photosynthesis by the plant. There were other carboxylic acids detected, yet their concentrations appear insignificant compared with that of acetate. The resultant biomass release is shown in Figure 3(a), where it compared to simulated biomass exudation by the Pandanus Amaryllifolius in maximum $\mathrm{CO}_{2}$ assimilation rate (Figure 3(b)) is estimated in around $0.254 \mathrm{mg} \mathrm{m}^{-2} \mathrm{~s}^{-1}$, and considering 12 hours of sunlight a day, the biomass accumulates up to $11 \mathrm{~g} \mathrm{~m}^{-2}$ a day using (10), which collates to $45.91 \%$ conversion efficiency when compared to the model. The lower conversion rate is more likely due to the utilized acetate substrate during P-MFC operation. 


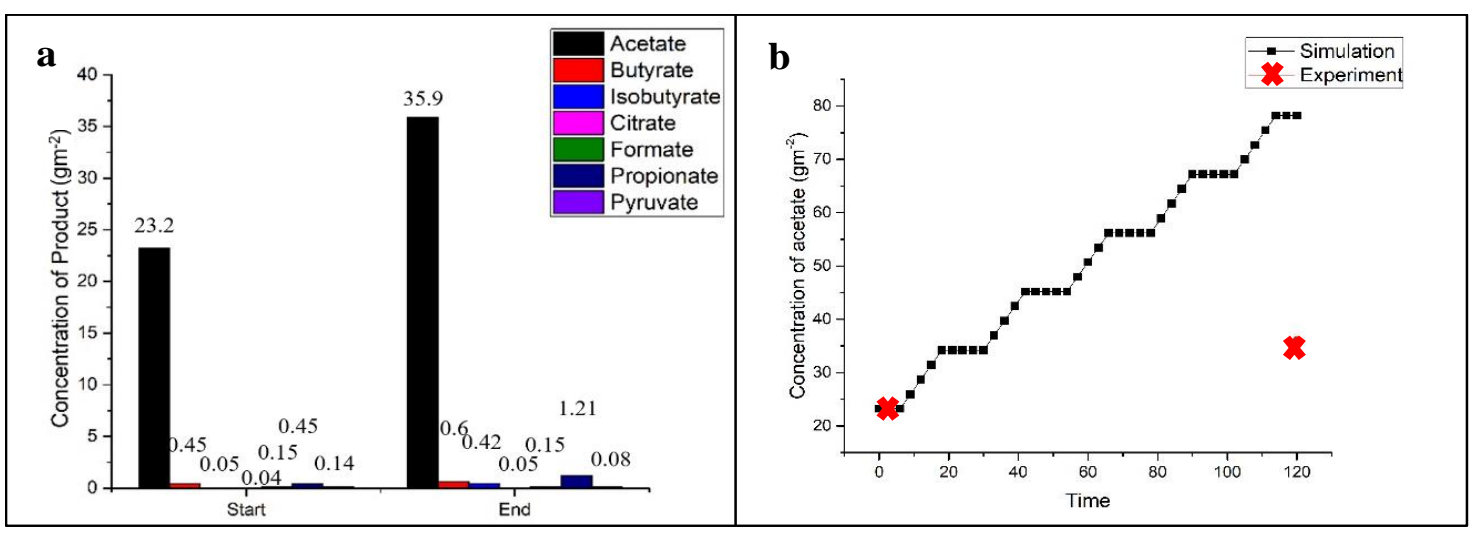

Figure 3. (a) Concentration of organic $\mathrm{C}$ compound in the soil at the start and the end of the monitoring process, (b) Comparison between the simulated concentration of acetate substrate and the actual data the start and the end of the experiment

\subsection{Electrical Energy Conversion Efficiency}

In order to calculate the coulombic efficiency, the internal resistance of the Pandanus Amaryllifolius was calculated using ohm's law, R=V/I [32]. Assuming the acetate was completely utilized to generate electricity using (15), Coulombic efficiency (CE\%) was then calculated as (17), where $C_{E x}$ are the total coulombs calculated with the integration of current measured over a time interval $(i)$, and $C_{T h}$ is the theoretical amount of coulomb from acetate.

$$
C E \%=\left[\frac{C_{E x}}{C_{T h}}\right] \times 100 \%
$$

Where

$$
\begin{aligned}
C_{E x} & =\sum_{i=1}^{T}\left[\frac{V_{i}}{R}\right]_{t_{i}} \text { and } \\
C_{T h} & =F_{a} b M v
\end{aligned}
$$

$F_{a}$ is the Faraday constant ( $96485 \mathrm{C} \mathrm{mol}^{-1}$ ), $b$ is the number of electrons produced per gram of the substrate ( $8 /$ gram acetate $), M$ is the acetate substrate concentration $\left(g^{-2}\right)$ and $v$ is the volume of the vessel $\left(m^{3}\right)$.

During the inoculation of bacteria, the internal resistance of P-MFC will be higher where the power generation will be lower described in Figure 4(a), averaging $1194.99 \pm 96.9 \Omega$. It was observed that the electrical power output curve from P-MFC in Figure 4(b) matches the bacterial logistic growth curve that plotted using (13) and parameters in Table 1, which starts from rest, exponential and stabilization. Coulombic efficiency of $95.32 \%$ was achieved when calculated using (17) where $C_{E x}=5223.08$ and $C_{T h}=5480.3$, utilizing the acetate substrate. In the conducted experiment, it was observed that the temperature hike increases the voltage output. Each hike in temperature during the middle of the day in Figure 4(b) shows an increase in voltage. The soil $\mathrm{pH}$ acidifies with time, verifies (15) with bicarbonate released during oxidation. This does not affect the power output of P-MFC but will affect plant health. Hence, distilled water is added to neutralize the acidic soil.

Verification of bacterial activity on the surface of the anode electrode was observed by using field emission scanning electron microscopy (FESEM). The attachment of bacteria biofilm [33] on the surface is shown in Figure 5. 


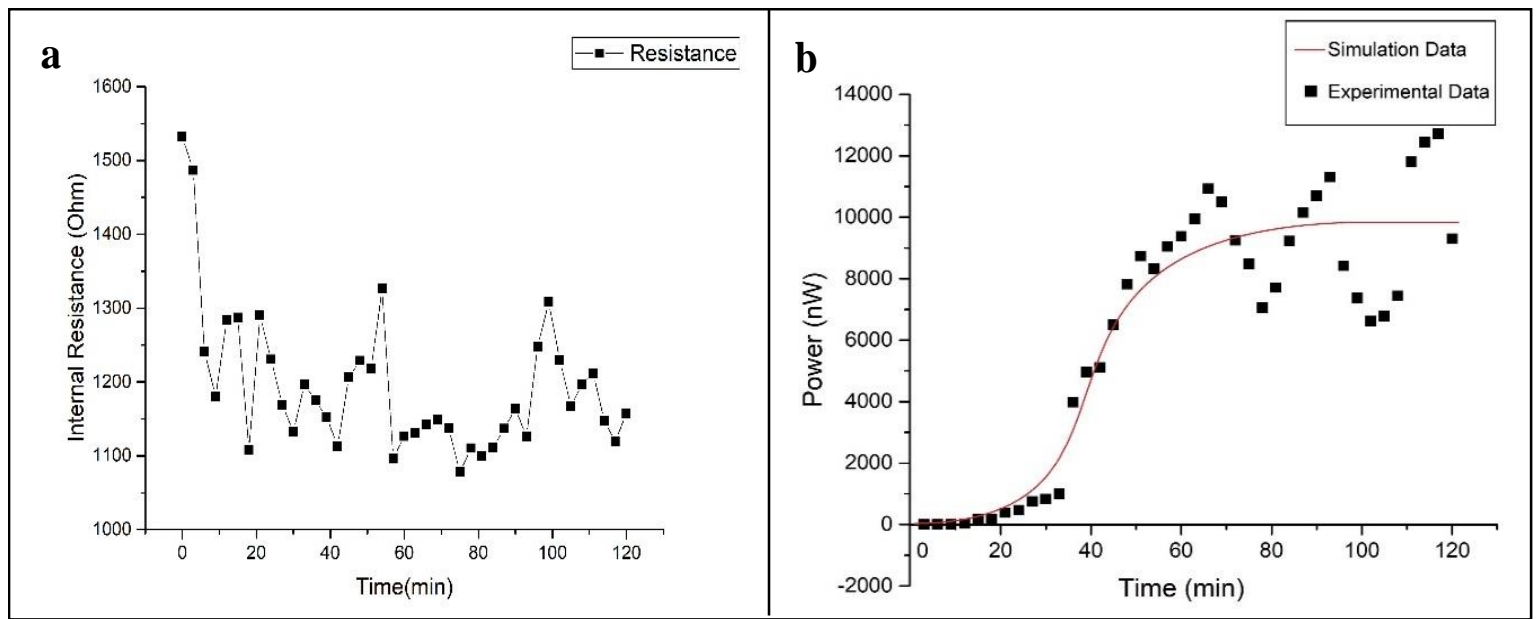

Figure 4. (a) Internal resistance of Pandanus Amaryllifolius P-MFC with time, (b) Comparison between bacteria growth curve simulated data and power generated by Pandanus Amaryllifolius P-MFC

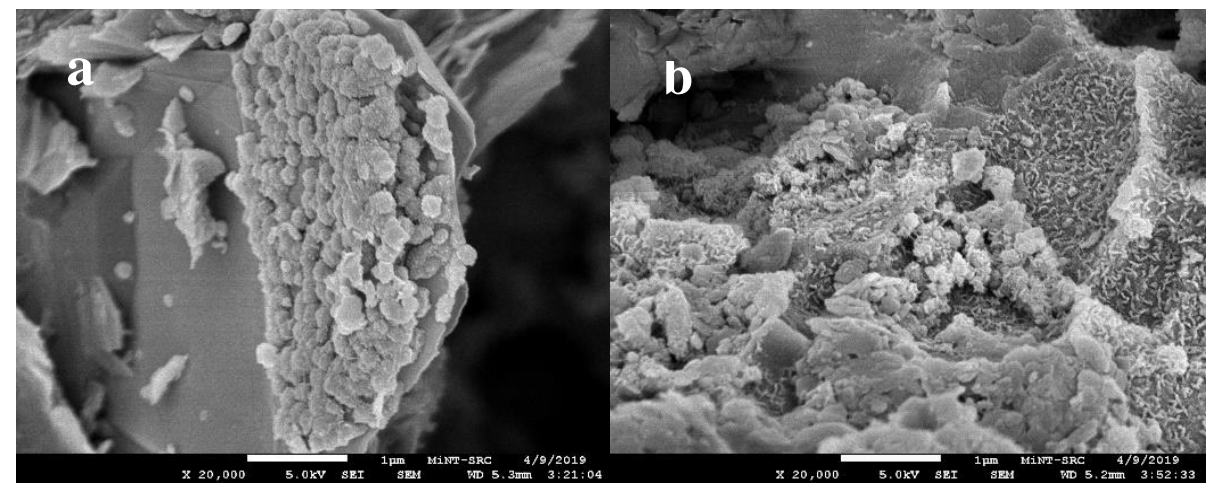

Figure 5. FESEM images (a) Bacterial biofilm on the surface of the anode electrode, (b) Colony of bacteria in the soil surround anode electrode

\section{CONCLUSION}

This study presents the analytical model for Pandanus Amaryllifolius P-MFC. These models illustrate the process from plant photosynthesis, $\mathrm{CO}_{2}$ assimilation, exudation of biomass, bacteria growth, consumption of substrate till the generation of electrical energy. Acetate production by rhizodeposition was predicted where the utilized acetate substrate managed to achieve up to $95.32 \%$ of coulombic efficiency of energy conversion. The model was validated with the extracted experimental data, which verifies the bacteria's continuous growth relationship with the power generation of P-MFC, while it seems more bacteria growth count will reduce the internal resistance where temperature contribute to reaction rate between chemicals in the soil. In contrast, the model indicates better electrical energy harvesting with a longer period of time. Hence, there exists a high similarity pattern in experimental data and modeling results.

\section{ACKNOWLEDGEMENTS}

The author gratefully acknowledges financial support from the Research Management Centre, UTHM under Grant (U957) and Research Fund (E15501).

\section{REFERENCES}

[1] M. Helder et al., "Electricity production with living plants on a green roof: environmental performance of the plantmicrobial fuel cell," Biofuels, Bioprod. Biorefining, vol. 6, no. 3, pp. 246-256, 2012.

[2] H. C. Teng, B. C. Kok, C. Uttraphan, and M. H. Yee, "A Review on Energy Harvesting Potential from Living Plants : Future Energy Resource,” Int. J. Renew. Energy Res., vol. 8, no. 4, pp. 2598-2614, 2018. 
[3] D. P. B. T. B. Strik, H. V. M. H. (Bert), J. F. H. Snel, and C. J. N. Buisman, "Green electricity production with living plants and bacteria in a fuel cell," Int. J. Energy Res., vol. 33, no. 4, pp. 23-40, 2008.

[4] B. Lóránt, M. Gyalai-Korpos, I. Goryanin, and G. M. Tardy, "Single chamber air-cathode microbial fuel cells as biosensors for determination of biodegradable organics," Biotechnol. Lett., vol. 4, pp. 555-563, 2019.

[5] R. E. Kannan and S. Saini, "Mathematical modelling of quorum sensing in bacteria," Math. Med. Biol., vol. 18, no. 3, pp. 263-292, 2018.

[6] M. Kazemi, D. Biria, and H. Rismani-Yazdi, "Modelling bio-electrosynthesis in a reverse microbial fuel cell to produce acetate from $\mathrm{CO}_{2}$ and $\mathrm{H}_{2} \mathrm{O}$," Phys. Chem. Chem. Phys., vol. 17, no. 19, pp. 12561-12574, 2015.

[7] C. Y. Ying and J. Dayou, "Modelling of the electricity generation from living plants," J. Teknol., vol. 78, no. 6, pp. 29-33, 2016.

[8] S. Liu, H. Song, X. Li, and F. Yang, "Power generation enhancement by utilizing plant photosynthate in microbial fuel cell coupled constructed wetland system," Int. J. Photoenergy, vol. 2013, 2013.

[9] N. Ueoka, N. Sese, M. Sue, A. Kouzuma, and K. Watanabe, "Sizes of Anode and Cathode Affect Electricity Generation in Rice Paddy-Field Microbial Fuel Cells," J. Sustain. Bioenergy Syst., vol. 06, no. 01, pp. 10-15, 2016.

[10] P. Chiranjeevi, G. Mohanakrishna, and S. Venkata Mohan, "Rhizosphere mediated electrogenesis with the function of anode placement for harnessing bioenergy through CO2sequestration," Bioresour. Technol., vol. 124, pp. 364-370, 2012.

[11] S. V. Madhavi and G. T. R. Das, "A robust H-infinity controller for an isolated boost converter used in fuel cell application,” J. Electr. Syst., vol. 15, no. 2, pp. 197-212, 2019.

[12] O. Garfi, H. Aloui, and N. Chaker, "Impacts of photovoltaic power source intermittence on a distribution network," vol. 9, no. 6, pp. 5134-5142, 2019.

[13] T. H. Cheng, K. B. Ching, C. Uttraphan, and Y. M. Heong, "Continuous Monitoring and Analysis of Pandanus Amaryllifolius Microbial Fuel Cell Power Generation in Daily Solar Radiation," Int. J. New Innov. Eng. Technol., vol. 12, no. 1, pp. 93-103, 2019.

[14] T. Horie and T. R. T. Sinclair, "Leaf nitrogen, photosynthesis, and crop radiation use efficiency: a review," Crop Sci., vol. 29, no. 1, p. 90, 1989.

[15] J. L. Monteith and C. J. Moss, "Climate and the Efficiency of Crop Production in Britain," Philos. Trans. R. Soc. B Biol. Sci., vol. 281, no. 980, pp. 277-294, 2006.

[16] X. Luo et al., "Comparison of Big-Leaf, Two-Big-Leaf, and Two-Leaf Upscaling Schemes for Evapotranspiration Estimation Using Coupled Carbon-Water Modeling," J. Geophys. Res. Biogeosciences, vol. 123, no. 1, pp. 207-225, 2018.

[17] L. Ran, J. Pleim, C. Song, L. Band, J. T. Walker, and F. S. Binkowski, "A photosynthesis-based two-leaf canopy stomatal conductance model for meteorology and air quality modeling with WRF/CMAQ PX LSM," J. Geophys. Res., vol. 122, no. 3, pp. 1930-1952, 2017.

[18] Y. Bai, J. Zhang, S. Zhang, F. Yao, and V. Magliulo, "A remote sensing-based two-leaf canopy conductance model: Global optimization and applications in modeling gross primary productivity and evapotranspiration of crops," Remote Sens. Environ., vol. 215, no. September, pp. 411-437, 2018.

[19] Z. M. Yasin, N. A. Salim, N. F. A. Aziz, H. Mohamad, and N. A. Wahab, "Prediction of solar irradiance using grey Wolf optimizer least square support vector machine," Indones. J. Electr. Eng. Comput. Sci., vol. 17, no. 1, pp. 10-17, 2019.

[20] N. Saad et al., "Solar irradiance uncertainty management based on Monte Carlo-beta probability density function : case in Malaysian tropical climate," Bull. Electr. Eng. Informatics, vol. 8, no. 3, pp. 1135-1143, 2019.

[21] L. Mwafulirwa et al., "Barley genotype influences stabilization of rhizodeposition-derived C and soil organic matter mineralization," Soil Biol. Biochem., vol. 95, pp. 60-69, 2016.

[22] T. Ge et al., "Rice rhizodeposition and its utilization by microbial groups depends on N fertilization," Biol. Fertil. Soils, vol. 53, no. 1, pp. 37-48, 2017.

[23] J. Pausch and Y. Kuzyakov, "Carbon input by roots into the soil: Quantification of rhizodeposition from root to ecosystem scale," Glob. Chang. Biol., vol. 24, no. 1, pp. 1-12, 2018.

[24] H. Wang et al., "High power density microbial fuel cell with flexible 3D graphene-nickel foam as anode," Nanoscale, vol. 5, no. 21, pp. 10283-10290, 2013.

[25] Y. Qiao, X.-S. Wu, C.-X. Ma, H. He, and C. M. Li, "A Hierarchical porous graphene/nickel anode to simultaneously boost the bio- and electro-catalysis for high performance microbial fuel cells," 2016.

[26] S. Ou, H. Kashima, D. S. Aaron, J. M. Regan, and M. M. Mench, "Multi-variable mathematical models for the aircathode microbial fuel cell system," J. Power Sources, vol. 314, pp. 49-57, 2016.

[27] A. Maitra and K. A. Dill, "Bacterial growth laws reflect the evolutionary importance of energy efficiency," Proc. Natl. Acad. Sci., vol. 112, no. 2, pp. 406-411, 2014.

[28] A. M. Speers and G. Reguera, "Electron donors supporting growth and electroactivity of geobacter sulfurreducens anode biofilms," Appl. Environ. Microbiol., vol. 78, no. 2, pp. 437-444, 2012.

[29] Z. I. Kimura and S. Okabe, "Acetate oxidation by syntrophic association between Geobacter sulfurreducens and a hydrogen-utilizing exoelectrogen," ISME J., vol. 7, no. 8, pp. 1472-1482, 2013.

[30] N. S. Hamal, Z. M. Isa, N. M. Nayan, M. H. Arshad, and N. A. Mohamad Kajaan, "Optimizing PEMFC model parameters using dragonfly algorithm: A performance study," IET Conf. Publ., vol. 2018, no. CP749, pp. 5312-5320, 2018.

[31] H. L. Song, Y. Zhu, and J. Li, "Electron transfer mechanisms, characteristics and applications of biological cathode microbial fuel cells - A mini review," Arab. J. Chem., 2015. 
[32] R. F. Mustapa, N. Y. Dahlan, I. M. Yassin, A. H. Mohd Nordin, and A. Zabidi, "Energy consumption prediction through linear and non-linear baseline energy model," Indones. J. Electr. Eng. Comput. Sci., vol. 17, no. 1, pp. 102-109, 2019.

[33] Y. Jung, J. Choi, S. Kim, and J. Lee, "Embedded Biofilm, a New Biofilm Model Based on the Embedded," Appl. Environ. Microbiol., vol. 81, no. 1, pp. 211-219, 2015.

\section{BIOGRAPHIES OF AUTHORS}

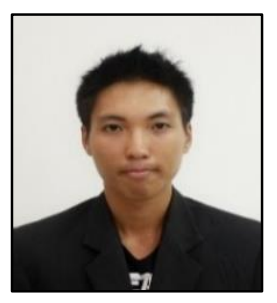

H.C. Teng is born in Kapit, Sarawak in Malaysia. He received his diploma of electrical engineering in 2012 from Kota Kinabalu Polytechnic, Sabah, Malaysia. He was awarded first class bachelor degree of electrical power engineering in 2017 from Universiti Tun Hussein Onn Malaysia, Johor, Malaysia. He is currently pursuing his Ph.D. degree in Universiti Tun Hussein Onn Malaysia, in the field of plant-microbial fuel cell.

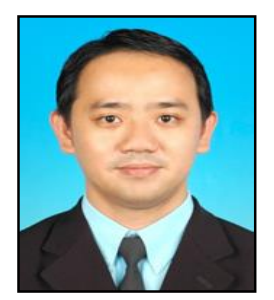

B.C. Kok obtained his B.Eng. (Electrical Engineering), M.Eng. (Power Systems) and Ph.D. (Power Systems) from Universiti Teknologi Malaysia (UTM) in 1998, 2001, and 2009, respectively. His technical interests are power system studies, energy savings, and renewable energy analysis. He is currently serving Universiti Tun Hussein Onn Malaysia (UTHM) as Associate Professor in the Department of Electrical Power Engineering, Faculty of Electrical and Electronic Engineering since 2016.

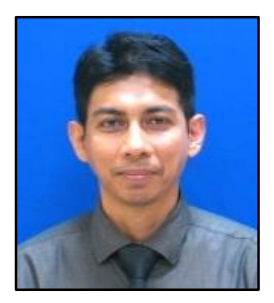

C. Uttraphan obtained his bachelor's degree in electrical engineering in 2002, master of electrical engineering in 2004 from Kolej Universiti Tun Hussein Onn Malaysia and Ph.D. degree of electrical engineering in 2016 from Universiti Teknologi Malaysia, Johor, Malaysia. His field of expertise is in IC design. He is currently a senior lecturer in Universiti Tun Hussein Onn Malaysia.

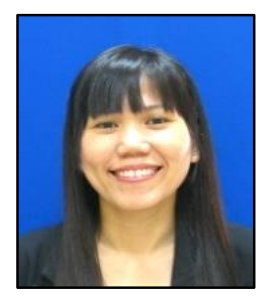

M.H. Yee obtained her bachelor's degree in technology and education in 2002, master of technical and vocational in 2004 and Ph.D. degree of technic and vocational education in 2015 from Universiti Teknologi Malaysia, Johor, Malaysia. Her field of expertise is in higher-order thinking skills (HOTS), learning and thinking styles and life-long education. She is currently a senior lecturer in Universiti Tun Hussein Onn Malaysia. 